Int. J. Dev. Biol. 61: 89-93 (2017)

doi: $10.1387 / \mathrm{ijdb} .160416 \mathrm{~cd}$

\title{
Changes in the expression of cyclin dependent kinase inhibitors during differentiation of immortalized fibroblasts into adipocytes
}

\author{
IBON ALONSO ${ }^{1}$, ANTONIO BAROJA ${ }^{1}$, BLANCA FERNÁNDEZ ${ }^{1}$, RAQUEL VIELBA², JON ELORRIAGA², \\ JAIRO PÉREZ-SANZ², JUAN ARÉCHAGA², JUAN J. GOIRIENA DE GANDARIAS ${ }^{1}$ and CARMEN DE LA HOZ*,2 \\ Departments of ${ }^{1}$ Physiology and ${ }^{2}$ Cell Biology and Histology, School of Medicine and Nursing, \\ University of the Basque Country (UPV/EHU), Leioa, Vizcaya, Spain
}

\begin{abstract}
The mechanisms implicated in the differentiation of fibroblastic precursors into adipocytes can be analyzed in vitro using cell models, such as the 3T3-L1 cell line. Since cell differentiation involves an exit from the cell cycle, it is likely that molecules that inhibit proliferation participate in the control of adipogenesis. This study was aimed at determining the role, if any, of several cyclindependent kinase (CDK)-inhibitors and the transcription factor C/EBP $\alpha$ in the process of adipocyte differentitation. We analyzed by Western blot the expression of distinct cyclin-dependent kinase (CDK)-inhibitors and C/EBP $\alpha$ during various stages of differentiation of 3T3-L1 cells to adipocytes. We observed specific changes in the expression of CDK inhibitors and C/EBP $\alpha$, during the various phases of adipogenesis. Levels of $\mathrm{p} 15^{\mathrm{INK} 4 \mathrm{~B}}$ were maximal in confluent cells prior to the induction of differentiation and minimal in differentiated cells. Maximal levels of $p 16^{\text {INK4A }}$ were detected following $48 \mathrm{~h}$ of differentiation treatment. Highest levels of $\mathrm{p} 18^{\mathrm{INK} 4 \mathrm{C}}$ were measured during the phase of cell confluence prior to treatment and in differentiated cells. $\mathrm{p} 21^{\mathrm{CIP} 1}$ was expressed during the exponential growth phase, during exit from clonal expansion, and in differentiated cells, while p27 ${ }^{\mathrm{KIP} 1}$ was found above all in confluent and differentiated cells. The present results support the participation of CDK-inhibitors in the process of in vitro adipogenesis. Specifically, the proteins p18INK4C, p21CIP1 and p27KIP1 seem to play an outstanding role in the maintenance of the differentiated state of adipocytes. Understanding the molecular mechanisms involved in adipocyte differentiation will presumably facilitate the design of new drugs aimed at novel therapeutic targets.
\end{abstract}

KEY WORDS: adipocyte, cell culture, CDK inhibitors, p18 $8^{I N K 4 C}, p 21^{C I P 1}, p 27^{K I P 1}$, C/EBP alpha

Immortalized fibroblast cell lines with the potential to differentiate into adipocytes have allowed the dissection of different stages of the process and offered the possibility of determining the relevant molecular players, which dynamically interact in a sequential cascade. The 3T3-L1 cell line is a well-established preadipose cell line that, under appropriate conditions, can acquire an adipocyte-like phenotype (Green and Meuth, 1974, Green and Kehinde, 1975, Armani et al., 2010, Ruiz-Ojeda et al., 2016). Taking into account that terminal differentiation of most cell lineages involves withdrawal from the cell cycle, it is reasonable to suppose that some of the molecules involved in the control of cell proliferation may well play a role in the process of adipocyte differentiation.

Two families of transcription factors largely control adipocyte differentiation: CCAAT/enhancer-binding proteins (C/EBPs) and peroxisome proliferator-activated receptors (PPARs) (Morrison and Farmer, 2000, Spiegelman et al., 2000). Ectopic expression of various C/EBPs has been shown to convert fibroblast cell lines into fully differentiated adipocytes (Lane et al., 1999), whereas C/ EBP gene knockouts block adipocyte differentiation (Wang et al., 1995). These transcription factors act in a sequential cascade; the expression of $\mathrm{C} / \mathrm{EBP}_{\mathrm{b}}$, and $\mathrm{C} / \mathrm{EBP}_{\delta}$ induces the expression of PPAR $_{\mathrm{g}}$ which in turn induces $\mathrm{C} / \mathrm{EBP}_{\mathrm{a}}$ expression. The latter slightly precedes the induction of most of the end product genes of fat cells. Although a relationship between adipocyte transcription factors and cell cycle control proteins is plausible, this has not yet been shown.

Abbreviations used in this paper: CDK, cyclin-dependent kinase; CKi, cyclin-dependent kinase inhibitor; DM, differentiation medium.

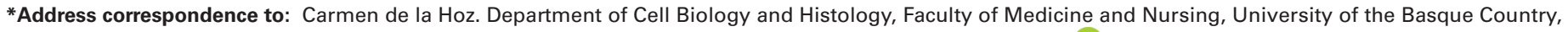
E-48940 Leioa, Vizcaya, Spain. Tel.: +34-94-601-2856. Fax: +34-94-464-8966. E-mail: carmen.delahoz@ehu.eus - iD http://orcid.org/0000-0001-6187-6813
} 
TABLE 1

\section{PERCENTAGE OF CELLS IN EACH PHASE OF THE CELL CYCLE, DURING THE DIFFERENTIATION OF 3T3-L1 CELLS TOWARDS ADIPOCYTES}

\begin{tabular}{lccccc} 
& A & B & C & D & E \\
\hline $\mathrm{G}_{0} / \mathrm{G}_{1}$ & $50.4 \pm 3.44$ & $59.9 \pm 0.66^{\star}$ & $26.1 \pm 7.07^{\star \star}$ & $58.26 \pm 3.7^{\star \star}$ & $67.47 \pm 1.93^{\star}$ \\
$\mathrm{S}$ & $7.2 \pm 0.26$ & $5.40 \pm 1.9$ & $11.3 \pm 2.6^{\star \star}$ & $4.86 \pm 0.11^{\star \star}$ & $5.60 \pm 0.23$ \\
$\mathrm{G}_{2} / \mathrm{M}$ & $31 \pm 1.8$ & $25.3 \pm 3.67$ & $48.4 \pm 3.59^{\star \star}$ & $27.4 \pm 4.41^{\star \star}$ & $21.46 \pm 3.49$ \\
Polyploid cells & $9.16 \pm 5.15$ & $6.5 \pm 3.45$ & $13.06 \pm 3.8^{\star}$ & $8.03 \pm 2.3^{\star}$ & $3.93 \pm 1.85^{\star}$
\end{tabular}

(A) Exponential growth; (B) $48 \mathrm{~h}$ confluent; (C) $24 \mathrm{~h}$ in differentiation medium; (D) $48 \mathrm{~h}$ in differentiation medium and (E) Sixth day after initiating the process of differentiation. Asterisks indicate statistical significance with respect to the previous state: ${ }^{*} p<0.05^{* \star} p<0.01$

Cyclin-dependent Kinase Inhibitors (CKIs) represent one of the main blocks for the progression of the cell cycle (Vidal and Koff, 2000, Sherr and Roberts, 1999). Several molecules of this kind have been described and are classified into two groups, known as the Ink4 and Cip/Kip families. Proteins in the Ink4 family p16 Ink4a, $\mathrm{p} 15^{\text {Ink4b }}, \mathrm{p} 18^{\text {Ink4c }}$ and $\mathrm{p} 19^{\text {Ink4d }}$ inhibit cyclin D-associated kinase activity. Proteins constituting the Cip/Kip family p $21^{\mathrm{Cip} 1}$, p2 $27^{\mathrm{Kip} 1}$ and p57 ${ }^{\text {Kip2 }}$ block Cdk2-Cyclin E complexes and can also inhibit Cdk4cyclin D activity under certain circumstances but their action in this context seems more complicated since they are also required for the proper formation of Cdk-cyclin complexes (Cheng et al., 1999).

Post-transcriptional mechanisms involving the 26S proteasome regulate the cyclin-dependent kinase inhibitors (CKIs), p21(Cip1) and p27(Kip1) during preadipocyte proliferation. A phytochemical agent, Helenalin, inhibits ubiquitination and degradation of p21 and p27 during $S$ phase progression and induces $\mathrm{G} 1$ arrest of synchronously replicating 3T3-L1 preadipocytes. It also increases p21 protein accumulation in both density-arrested and proliferating preadipocytes (Fernandes et al., 2008). Skp2 is necessary for p27 degradation and cell cycle progression during adipocyte differentiation. Another phytochemical agent, Curcumin, blocked Skp2 protein accumulation during early adipocyte hyperplasia, inducing p 27 protein accumulation and G1 arrest of synchronously replicating 3T3-L1 preadipocytes (Ferguson et al., 2016).

Protein p27 was present in the cytosol and nucleus in densityarrested preadipocytes and decreased as preadipocytes synchronously re-entered the cell cycle during early phases of adipocyte differentiation. p27 is ubiquitylated and targeted for degradation in the $26 \mathrm{~S}$ proteasome by distinct ubiquitin E3 ligases localized to the cytosol and nucleus during adipocyte hyperplasia (Auld and Morrison, 2006).

The current study shows the expression pattern of several CKIs during the process of adipocyte differentiation in 3T3-L1 cells, with a view to better understanding their role in this process. The fact that the expression of each protein varies in a distinct manner during adipocyte differentiation indicates that each of these proteins plays a distinct role in adipogenesis. Interestingly, the increased levels of $\mathrm{p} 18^{\mathrm{nk} 4 \mathrm{c}}, \mathrm{p} 21^{\mathrm{Cip} 1}$, and $\mathrm{p} 27^{\mathrm{Kip} 1}$ associated with the differentiated state, support the contribution of these proteins to this condition.

\section{Results}

\section{Cell cycle analysis of the differentiation process}

To evaluate the degree of adipocyte differentiation of 3T3-L1 cells 6 days after treatment (see Materials and Methods), the percentage of differentiated cells was quantified by Red Oil O staining. As shown in Fig. 1, the number of differentiated cells was clearly superior $(>80 \%)$ after differentiation treatment compared to control in which a small proportion of cells (8\%) spontaneously differentiated into adipocytes.

Flow cytometry curves of DNA content are presented in Fig. 2. The profile of cells in clonal expansion phase ( $24 \mathrm{~h}$ in differentiation medium) shows a drastic reduction in the number of cells in G0/G1 and a predominance of cells in S-G2/M phases (Fig. 2C).

The proportion of cells in different cell cycle stages in the different phases of differentiation is shown in Table 1. An increase $(p<0.05)$ in the percentage of cells in $G_{0} / G_{1}$ stage and a reduction in the other stages could be seen in $48 \mathrm{~h}$ confluent cells. In contrast, incubation for $24 \mathrm{~h}$ in the differentiation medium led to a reduction in the percentage of cells in the $\mathrm{G}_{0} / \mathrm{G}_{1}$ phase and an increase in the percentage of cells in the $S$ and $G_{2} / M$ phases in the clonal expansion stage $(\mathrm{p}<0.01)$. Following $48 \mathrm{~h}$ in differentiation medium, the percentage of cells in $G_{0} / G_{1}$ increased whereas it decreased in the $S$ and $G_{2} / M$ phases $(p<0.01)$ coinciding with the completion of the mitotic cycles. On the sixth day of differentiation, we observed an increase in the percentage of cells in $G_{0} / G_{1}$ $(p<0.05)$, which was higher than that observed in $48 \mathrm{~h}$ confluent cells. In contrast, the percentage of cells in $\mathrm{G}_{2} / \mathrm{M}$ decreased.

\section{Expression of cell cycle regulatory proteins}

Fig. 3A shows expression of members of CDK inhibitors from INK4 family. Namely, p15 $15^{\text {INK4b }}$ was found to be moderately expressed in exponentially growing cells (day -3) and intensely expressed following $48 \mathrm{~h}$ confluence (day 0 ). Subsequently, the
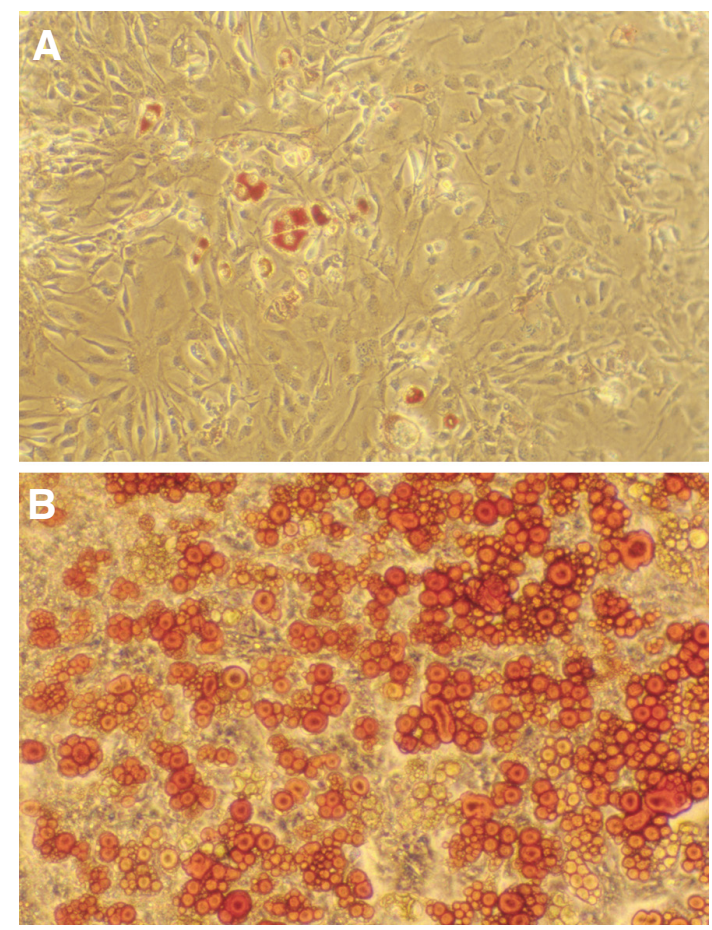

Fig. 1. Photomicrographs $(x 100)$ of 3T3-L1 cells in culture, stained with Red Oil to evidence lipid content. (A) Cells cultured in the usual medium (B) Cells incubated for 6 days in conditioned medium to induce their differentiation into adipocytes. The upregulation of lipid content following differentiation is evident. 

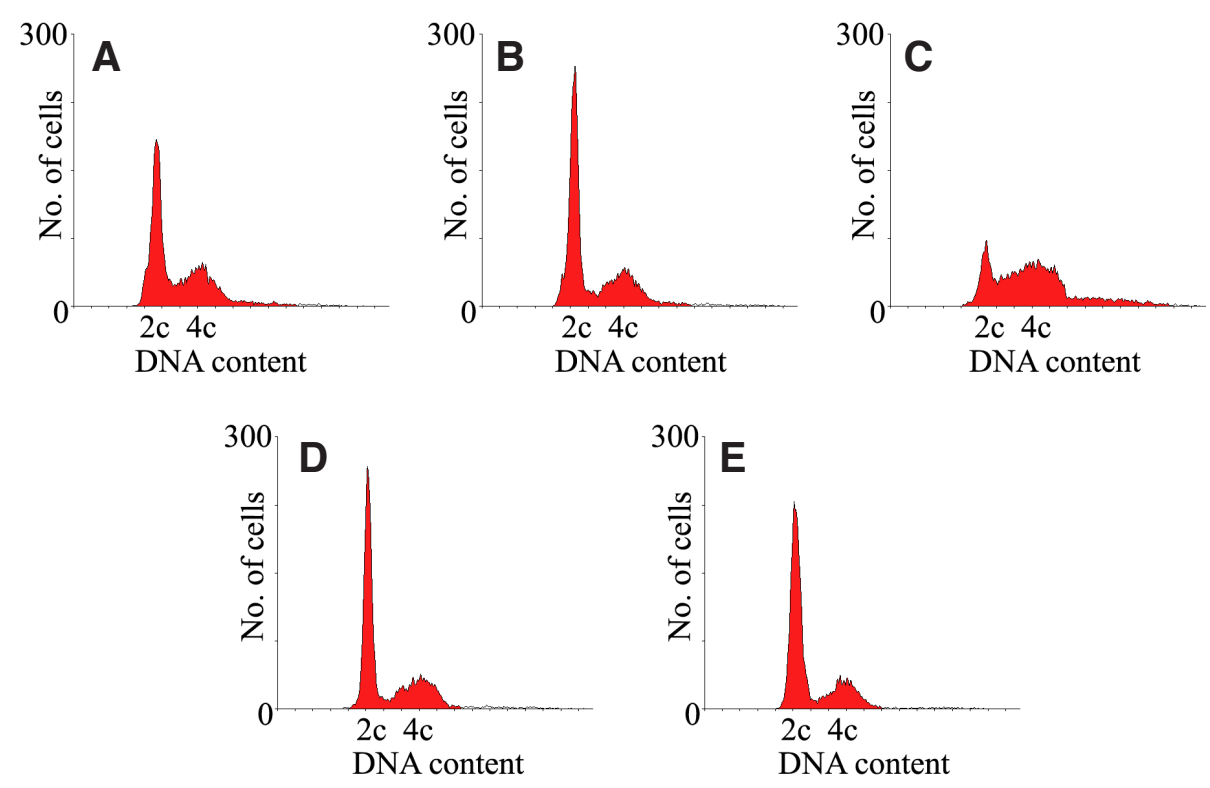

Fig. 2. DNA content in 3T3-L1 cells at five different stages of the differentiation process, evaluated by flow cytometry. (A) Exponentially growing cells; (B) $48 \mathrm{~h}$ confluent cells; (C) cells in differentiation medium (DM) for $24 \mathrm{~h}$ ("clonal expansion"); (D) cells in DM for $48 \mathrm{~h}$ (exit from clonal expansion); (E) cells 6 days after the induction of differentiation (see Materials and Methods).

the subsequent phases of differentiation, and reached maximal levels during the differentiated phase (day 6).

\section{Expression of the adipocyte transcription factor C/EBP $\alpha$}

As can be seen in Fig. $3 C$ this protein was practically undetectable during the initial phases of the process of differentiation. Increased levels were detected on day 2 when cells exit from the cell cycle prior to differentiation at the end of clonal expansion.

level of expression of this protein gradually declined during the remaining phases of the process of differentiation. The expression of $\mathrm{p} 16^{\text {INK4a }}$ gradually increased from the stage of exponential growth (day -3) to the phase of exit from clonal expansion (day 2), when its level of expression was found to be maximal. Expression of this protein dropped off noticeably when cells had already differentiated (day 6). The expression of p18 ${ }^{\mathrm{INK} 4 \mathrm{C}}$ oscillated considerably during the process of differentiation. Thus, expression of this protein increased notably in $48 \mathrm{~h}$ confluent cells (day 0 ) in comparison to cells in the exponential proliferation phase (day -3). In the following phases (day 1 and 2), it gradually declined to almost indetectable levels. Finally, in the differentiated stage (day 6), moderate levels of expression were once again detected.

Expression of CDK inhibitors from CIP/KIP family is shown in Fig. 3B. Higher expression of $\mathrm{p} 21^{\mathrm{Cip} 1}$ was found in cells which grew exponentially (day -3 ) than in $48 \mathrm{~h}$ confluent cells (day 0 ). During the following phases of differentiation, a gradual increase in the expression of this protein was observed, reaching maximal levels during the differentiated stage (day 6). P2 $7^{\text {Kip1 }}$ protein was expressed in exponentially growing cells (day -3). The expression of this protein rose considerably in $48 \mathrm{~h}$ confluent cells (day 0 ), but dropped off after incubation in differentiation medium during $24 \mathrm{~h}$ (day 1). Expression of this protein gradually increased during
Maximal expression of this transcription factor was detected during the differentiated stage (day 6).

\section{Discussion}

The present study shows changes in the expression of various cell cycle regulatory proteins during the process of differentiation from fibroblastic cells to adipocytes. The 3T3-L1 cell line reflects in vitro many of the biological aspects of the process of in vivo differentiation towards adipocytes. Using this tool, we have been able to figure out the role of these proteins in exit from the cell cycle and in the maintenance of the differentiated state.

In the process of differentiation there is growth arrest prior to the expression of differentiated characters and cells enter $G_{0}$. Differentiation of 3T3-L1 cells to adipocytes is connected to events within the cell cycle. Thus, in the exponential growth phase (Fig.2A) and in particular after $24 \mathrm{~h}$ of incubation in differentiation medium, i.e. clonal expansion phase (Fig. 2C), a high number of cells are in $S$ and $G_{2} / M$. In contrast, the majority of cells are in $G_{0} / G_{1}$ when at confluence (Fig. 2B) and upon finishing clonal expansion (Fig. 2D). Cells in $G_{0} / G_{1}$ also abound in the differentiated phase (Fig. 2E). Similar results were described by Simbulan-Rosenthal et al. (1996) in their study of the DNA replication complex during differentiation.
A

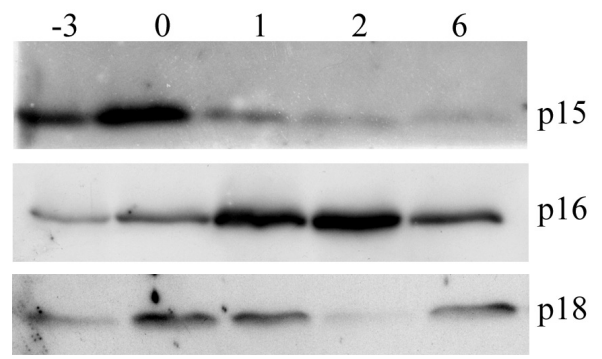

B

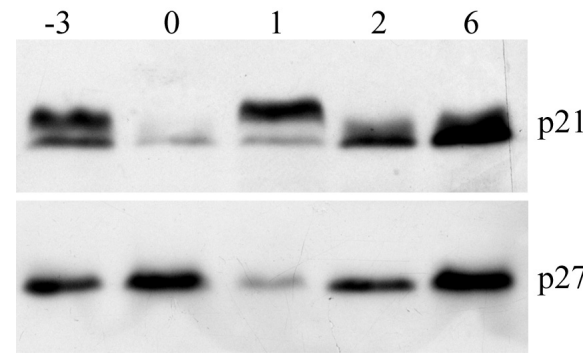

C

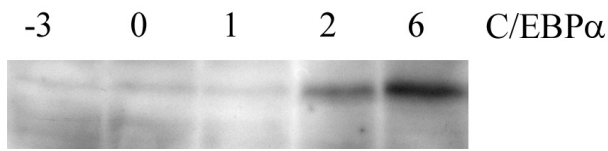

Fig. 3. Expression of CDK inhibitors $(A, B)$ and $C /$ EBP alpha (C) in the process of differentiation of 3T3-L1 cells into adipocytes. Measurements were performed using cells at different days/phases of the process: (-3) exponentially growing cells; (0) confluent culture, when differentiation medium was administered; (1) day 1 after the induction of differentiation; clonal expansion; (2) day 2 after differentiation induction; exit from clonal expansion and (6) differentiated cells 6 days after the initiation of induced differentiation (see Materials and Methods). 
In addition to changes in morphology and in the expression of certain genes, terminal differentiation is associated with loss of proliferative capacity, exit from $G_{1}$ and entry into $G_{0}$ quiescent stage. Since inhibitors of cyclin-dependent kinases play a main role in arresting the cell cycle, they may contribute to the exit from the cell cycle associated with differentiation and to the maintenance of the proliferative quiescence of differentiated cells. Thus, it would be reasonable to find higher levels of expression of CKIs in the phases of confluence, exit from clonal expansion and during the differentiated state. However, not all CKIs exhibited the same behavior. It is thus likely that in addition to their general function as inhibitors of proliferation, each of the CKIs plays specific roles within the process of differentiation of 3T3-L1 cells to adipocytes. According to our results, $\mathrm{p} 15^{\mathrm{INK} 4 \mathrm{~b}}$ would play a role in proliferative arrest associated with confluence in agreement with Phelps and Xiong suggestion (1998), P16 ${ }^{\text {INK4a }}$ would be involved in the initiation of growth arrest after clonal expansion in contrast with these authors who observed a pattern of expression similar to that of $\mathrm{p} 15^{\mathrm{INK} 4 \mathrm{~b}}, \mathrm{p} 18^{\mathrm{INK} 4 \mathrm{c}}$ would participate in the maintenance of the $\mathrm{G}_{0}$ state typical of differentiated cells as has been shown in other organs (Zindy et al., 1997),

p2 $1^{\text {Cip1 }}$ has been implicated in the terminal differentiation of various cell lines of epithelial origin and organs (Halevy et al., 1995, Zabludoff et al., 1998). There have been some discrepancies about the expression of this protein during this process. Our results coincide with those of Morrison and Farmer (1999) and Phelps and Xiong (1998), with the exception that we did not detect a fell off at the end of the process, neither did Reichert and Eick (1999). Our finding of high levels of $\mathrm{p} 21^{\mathrm{CIP} 1}$ in exponentially growing and clonal expansion cells is consistent with reports of increased expression of this protein when quiescent cells entered the cell cycle (Tian and Quaroni, 1999). Increased levels of $\mathrm{p} 21^{\mathrm{Cip} 1}$ during proliferation may be due to members of the CIP/KIP family acting as activators of Cdk4-6/Cyclin D as well as inhibitors of Cdk2 (Cheng et al., 1999). p27 ${ }^{\mathrm{Kip} 1}$ has been reported to participate in quiescence and in the terminal differentiation of different cells (Polyak et al., 1994; Tian and Quaroni, 1999) and the pattern of expression of p27 $7^{\text {Kip } 1}$ that we observed is consistent with this role and coincident with Morrison and Farmer (1999) and Phelps and Xiong (1998).

The cyclin dependent kinase inhibitor family is made up of seven members but it seems clear that the expression of only one CKI family member is sufficient to arrest the cell cycle. Since we observed the expression of various CKIs in each stage of the differentiation process, it seems likely that if one loses its function, this can be replaced by that of another member. Indeed, such a functional redundancy associated with important molecules is not a rare phenomenon in biological systems. Another possible explanation for the co-expression of CKIs during differentiation to adipocytes is their cooperation for growth arrest. This could take place between members of different CKI families, since those of the ankyrin family can only bind Cdk4-6/Cyclin D complexes, thus inducing the liberation of CIP/KIP proteins from these, favoring the subsequent inhibition of Cdk2-Cyclin E complexes (Reichert and Eick, 1999). After an analysis of our results, we propose the joint action of some of these CKIs. Thus, $p 15^{\text {INK4b }}-p 27^{\text {Kip } 1}$ and $p 18^{\text {INK4C }}$ p27 ${ }^{\text {Kip1 }}$ would participate in cell cycle exit for cells in confluence. Regarding quiescence prior to differentiation, cooperation between p16 ${ }^{\text {INK4a-p2 }} 1^{\text {Cip1 } 1}$ and p16 ${ }^{\text {INK4a }}-p 27^{\text {Kip1 }}$ may occur. Finally, cooperation between $p 18^{\text {INK4C }}-p 27^{\text {Kip1 }}$ and p1 $18^{\text {INK4C }}-p 21^{\text {Cip1 } 1}$ may occur in the quies- cent maintenance of the differentiated state. Members of the same family of CKIs may also cooperate; in particular, those that inhibit the activity of the Cdk2-Cyclin E complex, which phosphorylates p2 $7^{\text {Kip } 1 . ~ T h i s ~ r e s u l t s ~ i n ~ i t s ~ d e g r a d a t i o n ~ a n d ~ a s ~ a ~ c o n s e q u e n c e, ~ t h e ~}$ inhibition of Cdk2-Cyclin E maintains the activity of p27 ${ }^{\text {Kip1 }}$ (Sheaff et al., 1997). In this regard, p2 $1^{\text {Cip1 }}$ would cooperate with $\mathrm{p} 27^{\mathrm{Kip} 1}$ by complexing with Cdk2-Cyclin E, inhibiting its activity and provoking arrest following clonal expansion and the quiescent maintenance of the differentiated state.

$\mathrm{C} / \mathrm{EBP} \alpha$ is a main transcription factor in adipocyte differentiation, since it activates the transcription of adipocyte-specific genes. We observed an increase in its expression following $48 \mathrm{~h}$ in differentiation medium. Maximal expression was detected when the cells had differentiated into adipocytes. Similar results have been reported by others (Phelps and Xiong, 1998, Reichert and Eick, 1999, Yeh et al., 1995). Our results thus corroborate the participation of this transcription factor in the process of differentiation. C/EBP $\alpha$ is capable of inducing the expression of $\mathrm{p} 21^{\mathrm{Cip} 1}$ and of stabilizing this protein (Harris et al., 2001). This may explain the increased levels of p21 ${ }^{\mathrm{Cip} 1}$ which were observed in exit from clonal expansion and in differentiated cells, coincident with the time expression of $\mathrm{C} / \mathrm{EBP} \alpha$. Thus, the antiproliferative effect of $\mathrm{C} / \mathrm{EBP} \alpha$ reported by Timchenko et al., (1996) may be due to increased expression of p2 $1^{\text {Cip } 1 . ~ I n ~ a d d i t i o n ~ t o ~ i n d u c i n g ~ t h e ~ e x p r e s s i o n ~ o f ~} \mathrm{p} 21^{\text {Cip } 1}$ and to stabilizing this protein (Harris et al., 2001), C/EBP $\alpha$ can exert an antiproliferative effect via other mechanisms: a) activation of the Gadd45 gene (Reynisdóttir and Massagué, 1997), b) interaction with $\mathrm{Rb}$ and $\mathrm{p} 107$ which, when joined to $\mathrm{C} / \operatorname{EBP} \alpha$, inhibit the activity of Cdk2 kinase (Timchenko et al., 1999), c) complexing with E2F transcription factors, inhibiting their transcriptional activity (Slomiany et al., 2000) and d) association with Cdk4 which provokes its degradation (Wang et al., 2002). Our results show a correlation between the expression of $\mathrm{C} / \mathrm{EBP} \alpha$ and growth arrest in that $\mathrm{C}$ / EBP $\alpha$ is expressed on day 2, when the proportion of cells in the $S$ phase is reduced following clonal expansion. These data thus support the role of $\mathrm{C} / \mathrm{EBP} \alpha$ in the arrest of the cell cycle for the establishment of the differentiated state.

Overall, the present results reveal evident changes in the expression of Cdk inhibitors in different phases of the process of differentiation of 3T3-L1 cells towards adipocytes. The observed changes are indicative of distinct roles played by the studied proteins in the time sequence of events associated with differentiation.

\section{Materials and Methods}

\section{Induction of differentiation and cell cycle analysis of 3T3-L1 cells}

The cell differentiation protocol was adapted from Student et al., (1980). Briefly, 3T3-L1 preadipocytes (American Type Culture Collection) were cultured in Dulbecco's modified Eagle's medium (DMEM, Biochrom) containing $10 \%$ fetal bovine serum (FBS). Confluent cells were then incubated for two days in differentiation medium (DM) consisting of $10 \%$ FBS-DMEM supplemented with $0.5 \mathrm{mM}$ isobutylmethylxanthine, $1 \mu \mathrm{M}$ dexamethasone and $2 \mu \mathrm{M}$ insulin (all from Sigma). DM was then replaced by $10 \%$ FBS-DMEM with $1 \mu \mathrm{M}$ insulin. After 48 hours, cells were changed to $10 \%$ FBS-DMEM, which was replaced every 48 hours until the cells were used for experimentation. Five distinct phases of the process of in vitro differentiation were considered: 1) exponential growth phase (day -3); 2) confluence (day 0); 3) the clonal expansion phase (day 1); 4) the cycle exit phase subsequent to clonal expansion (day 2) and 5) the differentiation phase (day 6). Cells in each of these phases were obtained for analysis 
of cell cycle and protein expression. The accumulation of acyltriglycerides was measured by means of Red Oil O staining (Fig. 1). At the previously mentioned phases of the differentiation process, the percentage of cells in each of the stages of the cell cycle was measured using propidium iodide.

\section{Western blotting}

Cells were washed in PBS and incubated in trypsin-EDTA. Then, they were resuspended in RIPA buffer and further dissociated by passing various times through G21 needle followed by incubation on ice for 45 min and centrifugation at $10,000 \mathrm{~g}$ for $10 \mathrm{~min}$. Protein concentration was measured by bicinchoninic acid. Same quantity of protein was loaded into the different gel lanes. Proteins were separated under denaturing conditions and wet transferred to a nitrocellulose membrane (Protan $0.2 \mu \mathrm{m}$, Schleicher \& Schuel). Non-specific binding was blocked by incubation in TBS-Tween 20 plus $10 \%(\mathrm{w} / \mathrm{v})$ low-fat milk $3 \mathrm{~h}$ RT. Membrane was incubated with primary antibody $4^{\circ} \mathrm{C}$ ON gentle shaking. Three washes in buffer Tris $10 \mathrm{mM}, \mathrm{pH}$ 7.4 (Merck), NaCl 500 mM (Sigma) and Tween 20 0.1\% (v/v, Sigma) were followed by incubation with peroxidase-conjugated secondary antibody 1 hour RT, 3 buffer washes and incubation in chemiluminescence substrate (ECL+, Amersham Pharmacia Biotech). Band densities were quantified by blot scanning (GS-710 Bio-Rad) and Quantity One (Bio-Rad) software. Primary mouse monoclonal antibodies were IgG2a anti-p16 ${ }^{\text {INk4a }}$ clone F12 (Santa Cruz Biotechnology), IgG2b anti-p21 $1^{\text {Cip1 }}$ clone F5 (Santa Cruz Biotechnology), IgG1 anti-p27 ${ }^{\mathrm{Kip} 1}$ clone 57 , (Transduction). Primary polyclonal antisera were goat anti-p15 ${ }^{\text {INK4b }}$ (Santa Cruz Biotechnology), rabbit antip18 ${ }^{\text {INK } 4 \mathrm{C}}$ (Biosource). Peroxidase-conjugated secondary antibodies were rabbit anti-mouse (Dako), rabbit anti-goat (Dako), pig anti-rabbit (Dako).

\section{Acknowledgments}

This work has been supported in part by the Basque Government (Dept. of Education, Universities and Research, PI97/57 and PI99/156) to C.d.I.H. and Research Group Grants from the Basque Government (IT1125-16) and the University of the Basque Country (GIU16/O6) to J.A.; I.A. received scholarships from the University of the Basque Country and from the Jesús de Gangoiti Barrera Foundation.

\section{References}

ARMANI, A., MAMMI, C., MARZOLLA, V., CALANCHINI, M., ANTELMI, A., ROSANO, G. M., FABBRI, A. and CAPRIO, M. (2010). Cellular models for understanding adipogenesis, adipose dysfunction, and obesity. J Cell Biochem 110: 564-572.

AULD, C. A. and MORRISON, R. F. (2006). Evidence for cytosolic p27(Kip1) ubiquitylation and degradation during adipocyte hyperplasia. Obesity (Silver Spring), 14: 2136-2144.

CHENG, M., OLIVIER, P., DIEHL, J. A., FERO, M., ROUSSEL, M. F., ROBERTS, J. M. and SHERR, C. J. (1999). The p21(Cip1) and p27(Kip1) CDK 'inhibitors' are essential activators of cyclin D-dependent kinases in murine fibroblasts. EMBO J 18: 1571-1583.

FERGUSON, B. S., NAM, H. and MORRISON, R. F. (2016). Curcumin Inhibits 3T3L1 Preadipocyte Proliferation by Mechanisms Involving Post-transcriptional p27 Regulation. Biochem Biophys Rep 5: 16-21.

FERNANDES, K. M., AULD, C. A., HOPKINS, R. G. and MORRISON, R. F. (2008), Helenalin-mediated post-transcriptional regulation of p21(Cip1) inhibits 3T3-L1 preadipocyte proliferation. J Cell Biochem 105: 913-921.

GREEN, H. and KEHINDE, O. (1975). An established preadipose cell line and its differentiation in culture. II. Factors affecting the adipose conversion. Cell 5: 19-27.

GREEN, H. and MEUTH, M. (1974). An established pre-adipose cell line and its differentiation in culture. Cell 3: 127-133.

HALEVY, O., NOVITCH, B. G., SPICER, D. B., SKAPEK, S. X., RHEE, J., HANNON, G. J., BEACH, D. and LASSAR, A. B. (1995). Correlation of terminal cell cycle arrest of skeletal muscle with induction of p21 by MyoD. Science 267: 1018-1021.

HARRIS, T. E., ALBRECHT, J. H., NAKANISHI, M. and DARLINGTON, G. J. (2001). CCAAT/enhancer-binding protein-alpha cooperates with p21 to inhibit cyclin- dependent kinase-2 activity and induces growth arrest independent of DNA binding. J Biol Chem 276: 29200-29209.

LANE, M. D., TANG, Q. Q. and JIANG, M. S. (1999). Role of the CCAAT enhancer binding proteins (C/EBPs) in adipocyte differentiation. Biochem Biophys Res Commun 266: 677-683.

MORRISON, R. F. and FARMER, S. R. (2000). Hormonal signaling and transcriptional control of adipocyte differentiation. J Nutr 130: 3116S-3121S.

PHELPS, D. E. and XIONG, Y. (1998). Regulation of cyclin-dependent kinase 4 during adipogenesis involves switching of cyclin $D$ subunits and concurrent binding of p18INK4c and p27Kip1. Cell Growth Differ 9: 595-610.

POLYAK, K., KATO, J. Y., SOLOMON, M. J., SHERR, C. J., MASSAGUE, J., ROBERTS, J. M. and KOFF, A. (1994). p27Kip1, a cyclin-Cdk inhibitor, links transforming growth factor-beta and contact inhibition to cell cycle arrest. Genes Dev 8: 9-22.

REICHERT, M. and EICK, D. (1999). Analysis of cell cycle arrest in adipocyte differentiation. Oncogene 18: 459-466.

REYNISDÓTTIR, I. and MASSAGUÉ, J. (1997). The subcellular locations of p15(Ink4b) and p27(Kip1) coordinate their inhibitory interactions with cdk4 and cdk2. Genes Dev 11: 492-503.

RUIZ-OJEDA, F. J., RUPÉREZ, A. I., GOMEZ-LLORENTE, C., GIL, A. and AGUILERA, C. M. (2016). Cell Models and Their Application for Studying Adipogenic Differentiation in Relation to Obesity: A Review. Int J Mol Sci 17: E1040.

SHEAFF, R. J., GROUDINE, M., GORDON, M., ROBERTS, J. M. and CLURMAN, B. E. (1997). Cyclin E-CDK2 is a regulator of p27Kip1. Genes Dev 11: 1464-1478.

SHERR, C. J. and ROBERTS, J. M. (1999). CDK inhibitors: positive and negative regulators of G1-phase progression. Genes Dev 13: 1501-1512.

SIMBULAN-ROSENTHAL, C. M., ROSENTHAL, D. S., HILZ, H., HICKEY, R., MALKAS, L., APPLEGREN, N., WU, Y., BERS, G. and SMULSON, M. E. (1996). The expression of poly(ADP-ribose) polymerase during differentiation-linked DNA replication reveals that it is a component of the multiprotein DNA replication complex. Biochemistry 35: 11622-11633.

SLOMIANY, B. A., D'ARIGO, K. L., KELLY, M. M. and KURTZ, D. T. (2000). C/EBPalpha inhibits cell growth via direct repression of E2F-DP-mediated transcription. Mol Cell Biol 20: 5986-5997.

SPIEGELMAN, B. M., PUIGSERVER, P. and WU, Z. (2000). Regulation of adipogenesis and energy balance by PPARgamma and PGC-1. Int $J$ Obes Relat Metab Disord 24: S8-S10.

STUDENT, A. K., HSU, R. Y. and LANE, M. D. (1980). Induction of fatty acid synthetase synthesis in differentiating 3T3-L1 preadipocytes. J Biol Chem 255: 4745-4750.

TIAN, J. Q. and QUARONI, A. (1999). Involvement of p21(WAF1/Cip1) and p27(Kip1) in intestinal epithelial cell differentiation. Am J Physiol 276: C1245-C1258.

TIMCHENKO, N. A., WILDE, M. and DARLINGTON, G. J. (1999). C/EBPalpha regulates formation of S-phase-specific E2F-p107 complexes in livers of newborn mice. Mol Cell Biol 19: 2936-2945.

TIMCHENKO, N. A., WILDE, M., NAKANISHI, M., SMITH, J. R. and DARLINGTON, G. J. (1996). CCAAT/enhancer-binding protein alpha (C/EBP alpha) inhibits cell proliferation through the p21 (WAF-1/CIP-1/SDI-1) protein. Genes Dev10:804-815.

VIDAL, A. and KOFF, A. (2000). Cell-cycle inhibitors: three families united by a common cause. Gene 247: 1-15.

WANG, H., GOODE, T., IAKOVA, P., ALBRECHT, J. H. and TIMCHENKO, N. A. (2002). C/EBPalpha triggers proteasome-dependent degradation of cdk4 during growth arrest. EMBO J 21: 930-941.

WANG, N. D., FINEGOLD, M. J., BRADLEY, A., OU, C. N., ABDELSAYED, S. V., WILDE, M. D., TAYLOR, L. R., WILSON, D. R. and DARLINGTON, G. J. (1995). Impaired energy homeostasis in C/EBP alpha knockout mice. Science 269: 1108-1112.

YEH, W. C., CAO, Z., CLASSON, M. and MCKNIGHT, S. L. (1995). Cascade regulation of terminal adipocyte differentiation by three members of the C/EBP family of leucine zipper proteins. Genes Dev 9: 168-181.

ZABLUDOFF, S. D., CSETE, M., WAGNER, R., YU, X. and WOLD, B. J. (1998). p27Kip1 is expressed transiently in developing myotomes and enhances myogenesis. Cell Growth Differ 9: 1-11.

ZINDY, F., SOARES, H., HERZOG, K. H., MORGAN, J., SHERR, C. J. and ROUSSEL, M. F. (1997). Expression of INK4 inhibitors of cyclin D-dependent kinases during mouse brain development. Cell Growth Differ 8: 1139-1150. 


\section{Further Related Reading, published previously in the Int. J. Dev. Biol.}

Adipocyte is a non-trivial, dynamic partner of breast cancer cells

Jinxiang Tan, Emilie Buache, Marie-Pierre Chenard, Nassim Dali-Youcef, Marie-Christine Rio Int. J. Dev. Biol. (2011) 55: 851-859

http://www.intjdevbiol.com/web/paper/113365jt

Remodeling mechanisms of the mammary gland during involution

Christine J. Watson and Peter A. Kreuzaler

Int. J. Dev. Biol. (2011) 55: 757-762

http://www.intjdevbiol.com/web/paper/113414cw

Ecosystems of invasion and metastasis in mammary morphogenesis and cancer Marc Mareel and Susana Constantino

Int. J. Dev. Biol. (2011) 55: 671-684

http://www.intjdevbiol.com/web/paper/113386mm

Growth factor-defined culture medium for human mesenchymal stem cells

Sumiyo Mimura, Naohiro Kimura, Mitsuhi Hirata, Daiki Tateyama, Midori Hayashida, Akihiro Umezawa, Arihiro Kohara, Hiroki Nikawa, Tetsuji Okamoto and Miho K. Furue

Int. J. Dev. Biol. (2011) 55: 181-187

http://www.intjdevbiol.com/web/paper/103232sm

Brown adipose tissue as a derivative of mesoderm grafted below the kidney capsule. A model for differentiation of isolated rat mesoderm.

D Loncar

Int. J. Dev. Biol. (1992) 36: 265-274

http://www.intjdevbiol.com/web/paper/1525014

Development of thermogenic adipose tissue.

D Loncar

Int. J. Dev. Biol. (1991) 35: 321-333

http://www.intjdevbiol.com/web/paper/1814413

5 yr ISI Impact Factor $(2013)=2.879$

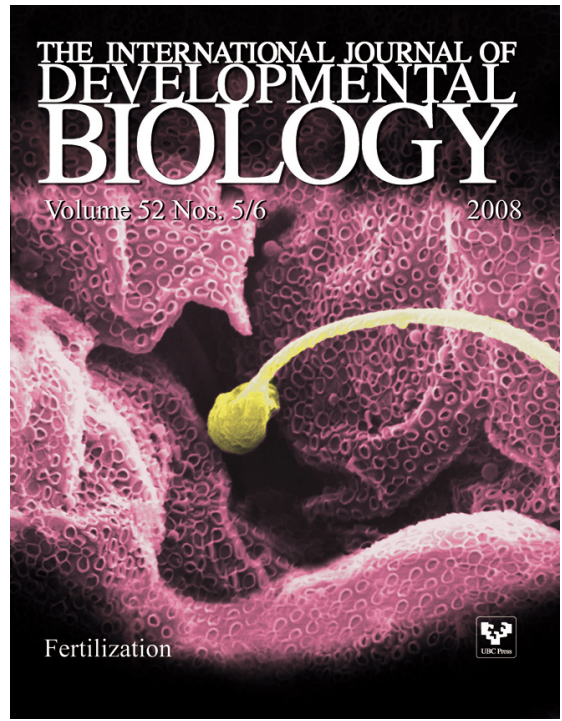

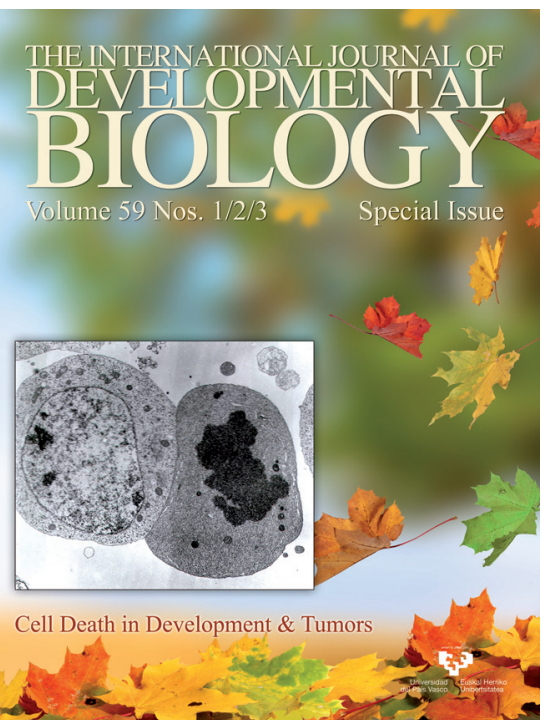
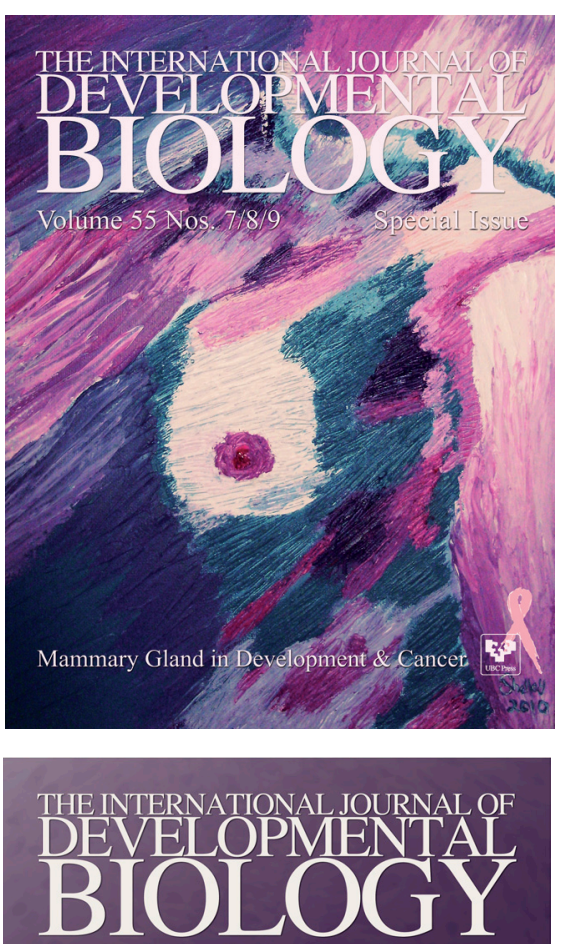

Volume 60 Nos. $10 / 11 / 12$

Special Issue

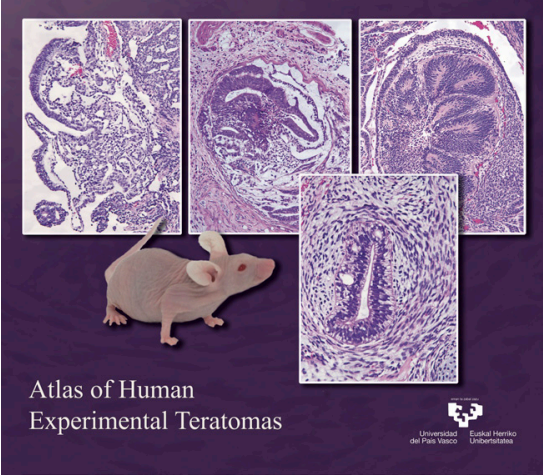

